\title{
Dynamic Role of Institutional Farmers in Clove Agribusiness
}

${ }^{1}$ Nur Azizah, ${ }^{2}$ Sitti Bulkis, ${ }^{3}$ Imam Mujahidin Fahmid, ${ }^{4}$ Muhammad Arsyad

${ }^{* 1}$ Doctoral Student, Hasanuddin University/Social Economic Agriculture, Makassar, South Sulawesi, Indonesia

${ }^{2}$ Professor Department of Socio-economics, Hasanuddin University/Faculty of Agriculture, Makassar, South

Sulawesi, Indonesia

${ }^{3}$ Lecturer of the Department of Socio-economics of Agriculture, Hasanuddin University/ Faculty of Agriculture, Makassar, South Sulawesi, Indonesia

${ }^{4}$ Lecturer of the Department of Socio-economics of Agriculture, Hasanuddin University/Faculty of Agriculture, Makassar, South Sulawesi, Indonesia

\begin{abstract}
The institutional improvement as an important issue in the 2014-2019 Ministry of Agriculture Strategic Plan (Renstra). The development of the agricultural sector that relies on natural resource management needs institutional regulation to synergize efforts that support each other in achieving goals. Institutional improvements in clove agribusiness include; upstream to downstream agribusiness institutions involving farmers, government institutions and business actors. All institutions involved have a role in clove agribusiness activities, institutional farmers included in the group are farmers whose members are clove farmers in the management of cloves and gapoktan as a combination of farmer groups. This study describes the role of farmer group institutions in the agribusiness system including upstream subsystems, farming subsystems and downstream subsystems in clove management. This research uses a case study method with a qualitative descriptive approach. Data collection on the role of the Mayou City Farmer Group and the Aru Jaya farmer group association (Gapoktan) was obtained from the results of the interviews with the help of questionnaires or questionnaires. The role of farmer groups in clove management is presented in a descriptive qualitative analysis. The results showed that the existence of Mayou City farmer group institutions had not played an active role in any clove farming activities, this was due to the inactivity and lack of role and participation of members who preferred to focus on their respective farming systems. Thus the care and activeness of a member in the Mayou City Farmers Group are caused by the needs and interests to be achieved. Then the role of Aru Jaya Gapoktan did not work as it should because since its formation, only carried out the management of horticultural cultivation, especially vegetables and have never touched on how clove cultivation as a hereditary plant has been carried out by local communities.
\end{abstract}

Keywords : Institutionalization, Farmer Group, Clove

\section{INTRODUCTION}

The concept of dynamics has been implemented in overcoming various agricultural development problems (Ha, et.al., 2017, Aymo, et.al., 2019). Much research on dynamics studies, specifically the institutional dynamics of rural land tenure in Huishan (Chen, 2017), joint management of smallscale fisheries (Leopold, et.al., 2019), project temporal arrangements (Dille, et.al., 2018), export and contract 
enforcement (Araujo, 2016) as well as the market situation of various actors (Ghaffari, et.al., 2019). The concept of dynamics in farmer groups can affect the ability of farmers to access information and inputs (Narloh, 2017), the dynamics of farmer participation in increasing financial and cultural benefits for farmers (Taylor, 2015). This research study focuses on the development of clove agribusiness, specifically the dynamics of the role of farmer institutions in clove agribusiness.

The development of clove agribusiness activities requires serious attention from all parties, both government, and community. One of the strategies carried out in the development of clove agribusiness for the purpose of increasing the production of agricultural products is an institutional improvement. The development of the agricultural sector that relies on natural resource management needs regulations and institutions to synergize mutually supportive efforts in achieving these targets. The institutional structure produces stability and flexibility in the government system (Beunen, 2017).

The farmer institutions included in this are farmer groups. Required in the management of factors of production, production processes, to the processing of products to the marketing of agricultural products. According to Hasibuan et.al., 2012; Mayasari and Nangameka, 2013; Ikbal, 2014, that farmer groups play a role in meeting the needs of production facilities as well as improving and developing the ability of farmers and their families as the subject of group approaches to be more involved in agricultural development. Farmer group institutionalization is expected to be able to help farmers get out of the problem of farmers' economic disparities in increasing productivity, farm efficiency, and farmer competitiveness, but until now it has not functioned optimally (Anantanyu, 2011). Farmer groups as a forum for farmers in activities ranging from the supply of seeds, fertilizers, medicines, maintenance to the marketing of clove products.

Gapoktan development is an advanced process of farmer institutions that have been running well as farmer groups. Gapoktan is positioned as an institution that coordinates the functional institutions that are below it, namely the farmer group. Gapoktan is an institution formed by the central government to assist the distribution of aid needs of farmers in Indonesia, because so far the government assistance has not been felt evenly by farmers, so every village in Indonesia was formed by the Association of Farmers Groups (GAPOKTAN) to facilitate the distribution of government assistance and accommodate the needs needed by farmers . Gapoktan cooperates with farmer groups, farmer groups are a group of farmers at the hamlet level. The farmer group is tasked with supervising farmers at the hamlet level, recording farmers' needs, finding solutions to the problems they face that are coordinating directly with Gapoktan (Handayani, 2013).

Institutional farmers involved in clove agribusiness are formed in farmer groups. One of the farmer groups located in East Tidore Subdistrict is the Mayou City Farmers Group, the Mayou City Farmers Group was formed with the facilitation of district extension workers. Based on the results of interviews with the head of the farmer group, it is known that members of the farmer group manage clove farming on each of their land, not in a clove plantation area. The development of the Mayou City peasant group from time to time has not increased its role in meeting the needs of its members.

One of the existing Gapoktan in the research area is Aru Jaya Gapoktan, which was established in 2012 
which is engaged in the cultivation of agricultural crops. The formation of the Aru Jaya Gapoktan is the result of deliberations by several heads of farmer groups facilitated by the District Extension Officers and develops from the interests and objectives to be achieved in an together.

\section{METHODS AND MATERIAL}

This study uses a case study method to find out social reality in depth from the role of farmer groups. The technique of determining informants in research uses purposive sampling and snowball techniques. Field data collection has been carried out systematically through in-depth interviews (Creswell, 1994). In addition, this research is accompanied by a focus group discussion (FGD) and field observations to understand the real conditions that occur. The study unit was obtained from the Mayou City Farmers Group and Aru Jaya Gapoktan. The target group is determined based on the identification of field conditions and preliminary information that has been obtained from key informants.

\section{DATA ANALYSIS}

The data analysis technique used in the research is the qualitative-descriptive analysis method. In this study, interview and observation data were written in a field note to be analyzed qualitatively and presented descriptively. Data analysis in qualitative research will take place simultaneously with other parts of the development of qualitative research, namely data collection and writing of findings (Daymon and Halloway, 2008).

\section{RESULTS AND DISCUSSION}

\section{a. Mayou City Farmers' Group}

Dynamics is something that means energy, strength, always moving, developing and able to adapt adequately to the situation. Dynamics also means there are interaction and interdependence between group members and the group as a whole. This situation can occur as long as there is in the group, therefore the group is dynamic, meaning that at any time the group concerned can change (Shaw, 1971). The running of a group can be seen from the dynamic of the group, both the group with its members and the members with the group members. Not a dynamic group can cause the group to live a name only. In addition, the group will survive if the group's goals are clear because today many groups are formed instantly that only meet the needs of a few people or irresponsible people. In other words, the group is formed when there is government funding assistance after the group is no longer running, for example, farmers' groups. The group is said to be dynamic if the group or organization is effective in achieving its goals. To find out whether a group is dynamic or not can be done by analyzing the behavior of group members through aspects or elements of group dynamics (Tuyuwale in Damima, 2001).

Based on the Regulation of the Minister of Agriculture Number.67/Permentan/ SM.050/12/2016, that in an effort to improve the ability of farmer groups must be able to carry out their roles as follows: (a) Learning Class, farmer groups are a place for teaching and learning for their members to improve their knowledge, skills in farming; (b) Collaboration Forum, a farmer group is a place to strengthen cooperation among fellow farmers in a farmer group and between farmer groups and with other parties; (c). Production Unit, farmer groups are directed to have the ability to make decisions in determining the development of profitable production. The dynamics of the role of farmer groups develop along with the development of clove agribusiness. Dynamics are seen as all changes in social institutions in a society, which affect its social system, including the values, 
attitudes, and patterns of behavior among groups in society (Soemardjan, 1963).

The development of the Mayou City peasant group from time to time has not increased its role in meeting the needs of its members. This is because even though farmers have formed groups, in their implementation, they have not demonstrated their existence as a group that helps develop their members to be able to increase their income and welfare, as stated by the head of the following farmer groups :

Each member of the farmer group does clove farming on each land owned individually, not in a clove plantation area that is managed in groups (Usman, 55 yr, interview 29/8/2018).

Likewise with an overview of the organizational structure that is complete with the duties and functions of each member, but in its implementation, it has not been well coordinated. Although a complete organizational structure has been compiled with the duties and functions of each member, it is difficult to realize in the field. The existing organizational structure seems to be just a name identity, without a harmonious coordination relationship.

The role of farmer groups in the upstream subsystem serves as a mediating medium for government policy, namely the extension of the clove seed aid distribution program. The policy of providing clove seedlings from the Department of Agriculture has indeed been implemented, but inadequate amounts. Distribution of seedlings is given to group leaders and then distributed to members of farmer groups, as stated below :

The Department of Agriculture provides clove seedlings to farmers, but the number of seeds is not enough, so not all farmers share clove seeds (Sadek, 53 yr, interview 20 September 2018).
In addition, most of the clove seedlings are procured by farmers from their own nursery activities. Knowledge and skills of farmers about clove nursery activities are obtained from the experience and learning from generation to generation by their parents.

The role of farmer groups in farming subsystems as a vehicle for cooperation between members of farmer groups involved in clove crop maintenance activities and at harvest Institutional agribusiness farming subsystems are farm business activities at the farm level that seek to manage inputs (seeds, land, labor, capital, technology) to produce agricultural products. Farmers carry out individual and group clove agribusiness subsystem activities. Clove planting activities are usually carried out by farmers themselves without involving farmer groups. Clove farming equipment procurement does not involve farmer groups, because there are no equipment resources owned by farmer groups, so clove farming equipment is obtained by making its own namely goka-goka and gates.

Farming equipment such as machetes, hoes, sickles, hitters, polybags and clove sacks are obtained by buying at farm shops, while goka-goka and gates are made of rattan with sacks (Usman, 55 yrs, interview, 9/22/2018).

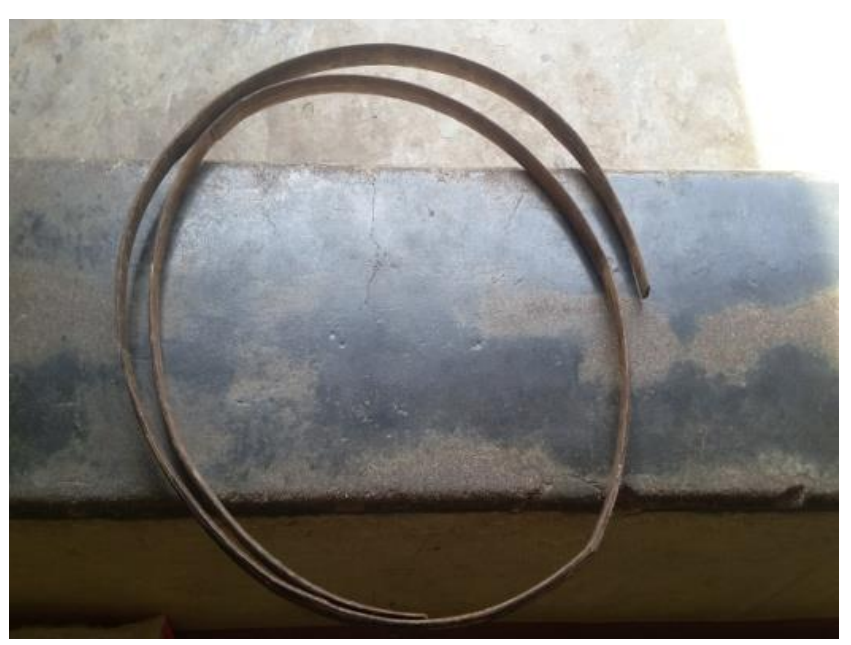




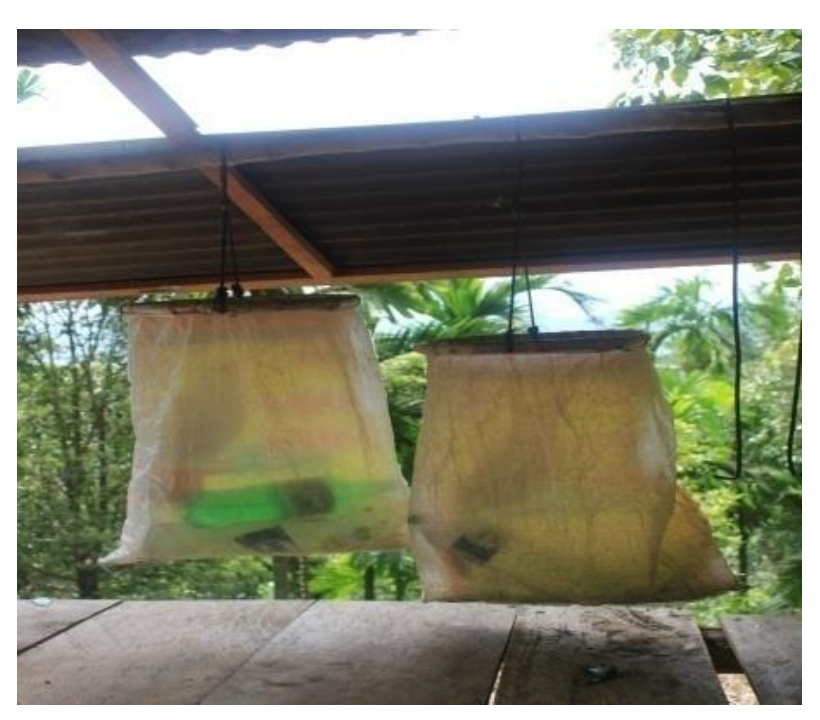

Figure 1. Clove Farmers' Harvest Equipment: a. Rattan; b. Goka-goka

The rules regarding the use of farmer group members in crop maintenance activities are agreed upon verbally. Workers used for clove farming are workers in the family and workers outside the family who come from farmer group members and local residents. The use of farmer group members in harvesting activities is based on mutually agreed rules. Harvest rules that apply in the form of rotating clove rotation time of each member of the farmer group. Norms that apply in harvesting activities are harvest time starts in the morning until late afternoon and the results obtained must be in the amount of 1 sack size of 30 $\mathrm{kg}$.

The role of farmer groups in the downstream subsystem as business units has not been felt by group members. Because farmers sell their own cloves, the marketing of cloves has not been organized in the container groups of farmers.

Clove marketing has not been coordinated by groups. Each member of the farmer group sells their cloves to the merchant collectors they subscribe to (Sadek, $53 \mathrm{yr}$, interview 20 September 2018).
The inability of the Mayou City farmer group to act as a business unit is due to the lack of capital resources used to accommodate the clove harvests of group members. The role of the farmer group as a business unit will be able to increase the bargaining power of farmers with traders so that they can determine the selling price of cloves and increase the profits from their sales. In line with research conducted by Barham, et.al., 2009, that the functioning of farmer group activities on the basis of capital assets will be able to influence the market situation

The role of farmer groups as business groups has not yet run maximally. Clove marketing activities have not been organized in a farmer group container.

Clove marketing has not been coordinated by groups. Each member of the farmer group sells their cloves to the collecting traders (Sadek, $53 \mathrm{yr}$, interview 20 September 2018).

Participation and roles of members are still lacking in the development of clove agribusiness. The reason for the lack of participation and role of members of farmer groups is because of the busyness of their farming business, besides those members of farmer groups are not interested in attending because they do not see the benefits to be gained. Mayou City peasant group activities are still lacking due to the absence of operational funds, there are no programs, other than that partly because the management or members are not active. The inactivity of the caretaker and members of the farmer group is also caused by a lack of concern and ability to adapt with other members to work together in a group. The participation of farmers in general as members of existing farmer groups depends on the needs and interests of farmers. If farmers feel the need and interest in group activities, farmers are motivated to 
participate. Member participation can be built or aroused by good leadership from group administrators, it could also be due to the attractiveness of activities to be carried out by groups (eg social gathering, recitation, savings and loans, and, mutual cooperation) (Purwantini, 2010).

The dynamics of the role of the Mayou City farmer groups have not been dynamic in clove agribusiness due to several factors, namely 1). The absence of routine meetings conducted by farmer groups to discuss all the problems faced; 2). The organizational structure and names of the administrators seem to be merely completeness of group administration. The existence of farmer groups should have a positive impact on group members in improving their standard of living (Safei et al. 2018).

\section{b. Farmers Group Gapoktan (Gapoktan) Aru Jaya}

Gapoktan development is an advanced process of farmer institutions that have been running well as farmer groups. Gapoktan is positioned as an institution that coordinates the functional institutions that are below it, namely the farmer group. The dynamics of the role of Gapoktan is in line with the development of farmer groups. The dynamics of studying the causes or factors that cause a group or organization can be dynamic, lively, moving, active, effective, efficient in achieving goals and productive to advance knowledge about the life of a group or organization (haw, 1971). The main role of Gapoktan is First, Gapoktan functioned as a central institution in the system that was built, for example, involved in the distribution of subsidized seeds that is tasked with recapitalizing the list of seed requests and the names of members. Second, Gapoktan is charged for increasing local-level food needs. Third, Gapoktan is considered a rural economic business institution (LUEP) so that it can receive capital-boosting funds, namely loan funds that can be used to purchase production facilities such as seeds, fertilizers, and medicines. Gapoktan is expected to be able to carry out fair and mutually beneficial partnership functions with saprodi traders and traders of agricultural products (Syahyuti, 2007). The formation of the Aru Jaya gapoktan is the result of deliberations by several heads of farmer groups facilitated by the District Extension Agency and develops from the interests and objectives that you want to achieve together. To achieve a common goal, Gapoktan members always hold meetings in the form of a collection of Koran which is carried out every Friday night. After conducting a joint study, the Gapoktan members discussed matters relating to the Gapoktan and their farming. Although meetings are always held, the concern of the members of the Gapoktan toward the Gapoktan program is still not optimal.

Since its inception, the Gapoktan Aru Jaya has only been managing horticulture, especially vegetables. Ardu Jaya Gapoktan does not only play a role to meet the needs of farmers but also tries to help farmers to increase knowledge and change the mindset of farmers who so far have been unable to accept the innovations and information provided because most of the members of Gapoktan are still poorly educated. Members of the Aru Jaya gapoktan, it is difficult to accept and implement innovations such as more profitable planting patterns, superior rice seeds, fertilizers, and medicines. Therefore Gapoktan strives hard to gradually illustrate the existence of innovations capable of increasing agricultural output.

Since Gapoktan exists until now, the extension activities carried out only for horticultural crops such as Tomatoes, Lombok, Kacang Panjang, Mustard. While counseling about how to cultivate cloves has never been carried out because farmers have adequate skills (Jainudin, $56 \mathrm{yr}$, interview 7/10/2018). 
The role of Gaputan Aru Jaya has been a medium for mediating the extension of government programs through the Department of Agriculture and BP3K. Based on interviews with the chairman of Gapoktan Aru Jaya, information was obtained that in 2013 Gapoktan received as much as 3000 clove seedlings distributed to both members and the community who wanted to plant them.

In addition, the Gapoktan also plays a role as a Rural Economic Business Institution (LUEP) so that it can receive a Capital Strengthening Fund (DPM), which is loan funds that can be used to obtain financial assistance for the provision of production facilities such as seeds, fertilizers, and medicines. However, these funds are intended only to provide production facilities for horticultural crops.

In 2012, Gapoktan received as much as 3000 clove seedlings and was distributed to members of the farmer group and not members of the farmer group who wanted to plant them, and in 2013, Gapoktan also received funding assistance for the purchase of seeds, fertilizers, and medicines for horticultural cultivation. (Jainuddin Laha, 56 yr, interview 10/10/2018).

The existence of subsidized fertilizer from the government allocated to meet the needs of farmers in the farming business is very helpful for farmers, especially for members who join Gapoktan or farmer groups. According to Lowisada (2014), which states that there is a supply of fertilizer at a cheaper price for Gapoktan compared to non-group members. Gapoktan members can make savings in farming production costs.

Aru Jaya Gapoktan is expected not only to play a role in the development of horticultural cultivation, but also for the development of clove agribusiness. In addition, Aru Jaya Gapoktan is expected to play a role in fulfilling agricultural capital, fulfilling production facilities, marketing agricultural products (including providing various information needed by farmers.

\section{CONCLUSION}

The role of the Mayou City Farmers Group has not increased in meeting the needs of its members. The organizational structure that has been prepared is difficult to be realized in the field because farmers usually plant cloves by themselves without involving farmer groups. The active role of the group is only seen during clove harvesting activities, namely when picking cloves from the tree. While the existence of Aru Jaya Gapoktan from the beginning only carried out the management of horticultural cultivation, but for extension of clove, cultivation has never been carried out. The dynamics of the role of farmer groups and farmer groups influence the development of farmer institutions in clove agribusiness activities.

\section{SUGGESTIONS}

The role of farmer groups and farmer groups needs to be more optimized in their role so that farmers are able to improve their performance in farming so they are able to create sustainable clove agribusiness.

\section{REFERENCES}

[1]. Aymo, Mahmoud, 2019. The Dynamic of Institutional Trading: Evidence From Transaction Data, The Journal Of Economics Asymmetries, Vol. 19.

[2]. Araujo, Luis, Giordano Mion, Emanuel Orneles, 2016. Institutions and Expert Dynamics, vol. 98. Pages 2-20.

[3]. Barham, James, Clarence Chitemi, 2009. Collective Action Initiatives To Improve Marketing Performance: Lessons From Farmer 
Groups In Tanzania, Journal Food Policy, Vol. 34 Pages 53-59.

[4]. Beunen, Raoul, James Patterson, Kristof Van Assche, 2017. Governing for Resilience: the role of institutional Jurnal Current Opinion Environmental Sustainability, Vol.28.

[5]. Chen, Cheng, Jinlong Gao, Jianglong Chen, 2017. Institutional Changes, Land Use Dynamics, and The Transition Of Rural Settlements in suburban China: A Case Study Of Hushian District in Wuxi City, Journal Habitat International, Vol.70. Pages 24-33.

[6]. Damima, V., 2001. Dinamika Kelompok Tani Padi Sawah di Kecamatan Tondano Kabupaten Minahasa. Metode-metode Riset Kualitatif Dalam Public Relations dan Marketing Communications. Penerjemah Cahya Wiratam, Bentang Pustaka. Yogyakarta.

[7]. Dille, Therese, Jones Soderlund, Stewart Clegg, 2018. Temporal Conditioning and The Dynamics of Inter-Institutional Project, International Journal Of Project Management, Vol. 36 Pages 673-686.

[8]. Gilles, Robert P, Emilia A.Lazarova, Pieter H.M.Ruys, 2015. Stability in A Network Economy; The Role Of Institutions, Vol. 119 (http//Journal Of Economic Behavior and Organizations).

[9]. Ha, Tuan, M, Ockie J.H.Bosch, Nam C.Nguyen, Chung T, 2017. System Dynamics Modelling For Defining Livelihood Strategic For Women Smallholder Farmers in Lowland and Upland Regions of Northern Vietnam: A Comparative Analysis, Journal Agricultural System, Vol.150, pages 12-20.

[10]. Handayani, S. 2013. Kelembagaan Agribisnis, (Online) (http://shsiskahan dayani.blogspot.com/2013/ 04/kelembagaanagribisnis.htmi
[11]. Hasibuan, Dewi Citra, Luhut Sihombing dan Emalisa, 2012. Peranan Kelompok Tani Terhadap Keberhasilan Penyaluran Pupuk Bersubsidi, Journal on Social Economic Of Agriculture And Agribusiness.

[12]. Ikbal, Muhammad, 2014. Peranan Kelompok Tani dalam Meningkatkan Pendapatan Petani Padi sawah di Desa Margamulya Kecamatan Bungku Barat Kabupaten Morowali, (Online), e-J.Agrotekbis Vol. 2: 505-509.

[13]. Lindner, Thomas, Jacob Muclliner,Jonas Puck, 2016 Cost of Capital in an International Context: Institutional Distance, Quality, and Dynamics, Jurnal International Of Manajemen, Vol.22,

[14]. Litbang. 2007. Analisis Kebijakan Pertanian, (http://www.Litbang. deptan.go.id/rppkVolume 5, No 1 Maret 2007.

[15]. Leopold, More, Oliver Thebaud, Anthony Charles, 2019. The Dynamics Of Institutional Innovation: Crafting Co-Management in Small Scale Fisheries Through Action Research, Journal Of Environmental, Vol. 237, Pages 187 -199 .

[16]. Lestari, Wahyu Puji, Diah Mardiningsih dan Siwi Gayatris, 2018. Peran Kelompok Tani Terhadap Tingkat Pengetahuan Petani Jambu Biji Getas Merah di Kelompok Tani Makmur Kecamatan PagerruyungKabupaten Kendal, Agrosaintifika Vol.2 No.1.

[17]. Mahsa, Ghaffari, Aliakbar Jafari, Ozlem Sandikci, 2019. The RoleMundane and Subtle Institutional Work in Market Dynamics: A Case of Fashion Clothing Market, Journal of Business Research.

[18]. Mayasari, Fitri, Yohanes Nangameka, 2013. Mempengaruh Keberadaan Kelompok Tani Terhadap Pendapatan Usaha Tani Tembakau (Studi Kasus di Desa Togosari Kecamatan Sumber Malang). 
[19]. Meddonca, Talles Girardi de, 2014. Institutions and Bilateral Agricultural Trade, Jurnal Procedia Economics and Finance, Brazil.

[20]. Mubay, Chipo Plaxedes, Paramu Mafongoyab, 2017. The Role of Institutions in Managing Local Level Climate Change Adaptation in Semi Arid Zimbabwe, http;//Journal Climate RiskManagement, Vol.16.

[21]. Moleang,L.J. 2010, Metodologi Penelitian Kualitatif, PT. Remaja Rosdakarya, Bandung

[22]. Moshinian, Fariborz., 2013. Market and Institutions: Global Perspektive, (Journal of Banking Finance, University Of Roma, Italy).

[23]. Nasrul, Wardy., 2012. Pengembangan Kelembagaan Pertanian Untuk Peningkatan Kapasitas Petani terhadap Pembangunan Pertanian, Menara Ilmu (Online), Vol. III No.29.

[24]. Narloch, Ulf, Adam G.Drucker, Unai Pascual, What Role For CoopertionIn Consevation Tenders? Paying Farmer Groups in The High Andes, Journal Land Use Policy, Vol 63 Pages 659-671.

[25]. Nielsen, Helle Orsted, Pia Frederiksen, Heli Saarikoski, Anne Mari Rytkönen, Anders Branth Pedersen, 2013. How Different Institutional Arrangements Promote Integrated River Basin Management. Evidence from the Baltic Sea Region, Journal Lands Use Policy, (https:

//www.sciencedirect.com/science/article, Vol.3 No.1.

[26]. Nugrohowardhani, 2015. Kelembagaan dan Pembangunan Desa. (http;//repository.uksw.edu/bitstream), Vol. 1.

[27]. Peraturan Menteri Pertanian Republik Indonesia, Nomor 77/permentan/ sm.050/ 12/2016 Tentang Pembinaan Kelembagaan Petani.
[28]. Rencana Pembangunan Jangka Menengah Daerah (RPJMD) Kota Tidore Kepulauan Tahun 2016-2021.

[29]. Rencana Strategis (Renstra) Kementrian Pertanian Tahun 2015- 2019.

[30]. Shaw, Marvin, E. 1971. Dinamika Kelompok, Psikologi Perilaku Kelompok Kecil.

[31]. Soemardjan, Selo, 1963. The Dynamics of Community Development in Rural Central and West Java a Comparative Report.

[32]. Taylor, B, M, M.Van Grieken, 2015. Local Institutions and Farmer Participation In Agrienvironmnetal Schemes, Journal of Rural Studies, Vol.17, Pages 10-19.

\section{Cite this article as :}

Nur Azizah, Sitti Bulkis, Imam Mujahidin Fahmid, Muhammad Arsyad, "Dynamic Role of Institutional Farmers in Clove Agribusiness", International Journal of Scientific Research in Science and Technology (IJSRST), Online ISSN : 2395-602X, Print ISSN : 2395-6011, Volume 6 Issue 5, pp. 266-274, September-October 2019. Available at doi : https://doi.org/10.32628/IJSRST196534 Journal URL : http://ijsrst.com/IJSRST196534 